\title{
MOBILE CONSUMER BEHAVIOUR ON APPS USAGE: THE EFFECTS OF PERCEIVED VALUES, RATING, AND COST
}

\author{
Izzal Asnira Zolkepli ${ }^{\mathrm{a}}$, Sharifah Nadiah Syed Mukhiar ${ }^{\mathrm{b}}$, Chekfoung Tan ${ }^{\mathrm{c}}$ \\ ${ }^{a, b}$ School of Communication, Universiti Sains Malaysia, \\ ${ }^{c}$ School of Computing \& Engineering, University of West London
}

\begin{abstract}
The rapid development of technology and the use of smartphones and mobile applications (apps), have become significant and influential in today's living. Despite the growing amount of research on mobile apps usage, little is known on the role they play in shaping the behaviour of the mobile consumer. By deploying the framework, this study revises Sheth's fundamental propositions of consumption values. While the fit of values has been recognised by many earlier behavioural studies, insight into the theoretical interface in mobile communication studies remains unsubstantiated. Therefore, this study explores the perceived consumption values on mobile apps behaviour and investigates the role of the rating of the apps and cost in influencing behaviour. A total of 392 questionnaires were collected through an online survey with 9 hypotheses examined. The analysis of the structural equation modelling determined a final model with four significant factors (functional, social, emotional, and conditional values). It confirmed that the usage is influenced by the apps rating and cost towards a certain degree. This study indicates the potential significance variables in mobile consumer literature and sheds light on mobile communication marketing in the area of apps marketing, specifically in designing effective user-experience (UX) apps for mobile consumers.
\end{abstract}

Keywords: Mobile Apps Marketing, Perceived Values, Mobile Communication, Mobile Behaviour, Smartphone Users

\section{Introduction}

In this new era of smartphones, mobile apps are capable of addressing almost every aspect of an individual's life and transforming various facets of society. Recent statistics show that smartphone penetration passed $50 \%$ of the global population in 2017 , and it is expected to exceed 6.1 billion by 2020 (Hsiao, Shu, \& Huang, 2017). The two biggest channels mobile consumer used to download the apps are through the Google Play Store and the iOS App Store. The total apps downloaded in 2018 was a staggering 105.3 billion. Google Play dominates nearly three quarters of downloads (76 billion downloads) that shows an increase of $13 \%$ over 2017. The App Store also grew in terms of download numbers, but at a slightly slower rate of $7 \%$, to reach 30 billion in 2018 . These statistics cover the first time download made through two channels (Iqbal, 2019). The numbers have uncovered an extensive use of smartphones, where mobile apps have tremendously contributed to the wellbeing of modern consumers (Tarute, Nikou, \& Gatautis, 2017).

The complex behaviour of modern consumers, has compelled app developers and marketers to constantly compete with each other, to provide a wide range of mobile services. The features offered by mobile apps services, have to support the locality, functionality, sociability, and mobility of the users, which require thoughtful research. Unsurprisingly, several issues arise from this situation in terms of how to acquire and retain mobile apps users, how to satisfy them, and how the mobile business can benefit from the users' continuous usage of their apps. It is important to determine the factors that influence mobile behaviour before downloading apps, hence the usage. From the developer and marketer's perspectives, it indicates factors that assist 
them to maximize revenue. Mobile apps are now functioning as a retail product (McLean, AlNabhani \& Wilson, 2018). Therefore, the factors influencing usage may be varied depending on the set of values associated with it.

Reflecting contemporary, increasingly dynamic and interactive innovative mobile environment, technology adoption research has received scholarly attention and revealed the insightful influence of perceived values on the users' decision towards digital devices (Dovaliene, Masiulyte, \& Piligrimiene, 2015; Hsiao \& Chen, 2016; Hsiao, 2017; Zhang, Li, $\mathrm{Wu}, \& \mathrm{Li}, 2017)$, which has guided this study in assessing mobile consumer perceived values on mobile apps. There is a mutual consensus among previous scholars who adopted the similar concept of values in various research settings, such as identifying the users' intention for continuance usage (Wang, 2014; Zhang et al., 2017), purchase behaviour (Hsiao \& Chen, 2016; Hsieh, 2016), and the prediction of brand loyalty (Candan, Unal, \& Ercis, 2013; Kumar, Purani \& Viswanathan, 2018). In the expanse of mobile consumer behaviour, it received minimal academic attention within the communication and marketing literature. Further, Cata and Martz (2015) articulated that an app's rating and cost, has a certain level of impact on determining mobile consumer behaviour. Hence this study assimilates it as mediators for smarter business strategy. The intervention strategies aim to invoke behavioural change in mobile consumers, as the demand of the mobile market towards more sophisticated apps is increasing based on the number stated earlier (Iqbal, 2019). As pointed out by Zolkepli \& Kamarulzaman (2015), studies on behavioural intervention observed varying degrees of success, but hardly explained why certain interventions succeeded or failed. Therefore, the mediation effect of apps rating and cost is tested to prove such degree of effect on the overall proposed framework.

By and large, this study recommends a framework that incorporates perceived values, cost, and rating that can be employed to assess the antecedents of the mobile apps usage behaviour. It also develops the directional and causality relationship between mobile apps' perceived values, apps rating, and apps cost. It contributes to the theory and practice in three aspects. First, it intends to extend Sheth's Consumption Values Theory (CVT) in the mobile behaviour context. Prior studies mainly employed this theory in the area of online and offline consumer behaviour, but not in the mobile behaviour study. Secondly, mobile communication is an emerging issue especially in the area of marketing and digital strategy, but most analyses has been performed from the perspective of user-experience context and content, and studies have rarely discussed mobile consumer behaviour. Lastly, attention has mostly been given to understanding behavioural aspect from the context of technology acceptance and adoption, using Technology Acceptance Model (TAM), Unified Theory of Acceptance and Use of Technology (UTAUT), and Theory of Planned Behaviour (TPB). Few studies have explored mobile consumer perception on apps values through the value perspective that overlooks the details of mobile apps features, development, usability, compatibility, and complexity. With the recent rapid development of the mobile apps market, this study is expected to bring greater insight about mobile consumer behaviour, to help mobile service providers in designing, customising, and innovating more noteworthy mobile apps to cater to customers' needs and expectations. Further on this is detailed in Table 1.

\section{Theoretical Framework \& Hypotheses Development}

\section{Concept Explication of Perceived Values}

The concept of perceived value emerged as one of the dominant business concern in the 1990s. Since then, it has continued to receive extensive research interest. These developments reflect 
that there is a great interest that has been generated by the phenomenon of value creation among marketing researchers in both academia and industry (Sánchez-Fernández \& Iniesta-Bonillo, 2007). Despite the wide interest in the study of value, the misconception of the term occurred in many subject areas. Innumerable definitions of perceived values have been propounded by some of the dominant scholars, including Holbrook (1999), Woodruff (1997), and Zeithaml (1988). Of these, one of the more commonly referred definitions is by Zeithaml (1988), that explained 'value' as:

... the consumer's overall assessment of the utility of a product based on perceptions of what is received and what is given (page 7).

Ziethaml (1988) views value as a unidimensional construct that can be measured by asking respondents to rate the value that they received in making their purchases. However, other scholars have recommended that the concept of value represents a more narrow approach and shall be treated as a multi-dimensional construct with a variety of notions (Sweeney and Soutar, 2001). According to Sheth, Newman \& Gross (1991), value rests on three fundamental propositions: (i) that market choice is a function of multiple values; (ii) that these forms of value make differential contributions in any given choice situation; and (iii) that the forms of value are independent which formed into functional, conditional, social, emotional, and epistemic. However, subsequent studies on values have focused mainly on the lack of generalizability of its original conceptualization. In this regard, Sweeney and Soutar (2001) developed measures for the three dimensions of value in the original multi-dimensional scale that is functional, social, and emotional. They omitted measures for epistemic value and conditional value because these are momentary.

Correspondingly, Williams and Soutar (2000) analysed the proposed dimensions of value in a tourism context, but the results indicated that four of the value categories from Sheth et al. (1991) were significant, and disregard conditional. Soon after, Sweeney and Soutar (2001) measured consumers' perceptions of the value on durable goods, and identified four value dimensions to be significant (emotional, social, quality/performance and price/value for money), and disregard epistemic and conditional value. Wang (2014) also adapted the framework suggested by Sweeney and Soutar (2001) and include in sacrifices, time, effort, and energy. All dimensions of perceived value and perceived sacrifices were found to have a significant effect on customer satisfaction, although no significant evidence was found to support the direct influence of any dimensions of value. Pura (2005) analysed the direct effect of the dimensions of perceived value on attitudinal and behavioral components of loyalty in mobile telephony services. In this context, Pura defined six dimensions - monetary, convenience, social, emotional, conditional, and epistemic. Pura adapted the functional dimension to the electronic service context and depicted it by monetary value and convenience value. These various contributions adapted Sheth et al. (1991) in many study contexts.

Fast forward to the present day, perceived values studies on technological product and user behaviour tend to be varied. Where considerable attention was given with the Technology Acceptance Model (Davis, 1989), Information Systems Success Model (Delone, 2003), and Expectation-Confirmation Model (Bhattacherjee, 2001) that can be explained through the systematic literature review done from 2015-2019 as depicted in Table 1. Factors such as performance expectancy, perceived usefulness, information quality, system quality were identified to affect the continuance behaviour of a technological product. Mobile apps studies so far have focused on the behaviour formed based on the technological product performance perspectives rather than the consumption value aspects. The original study on values has been 
deserted along the way, with the dominance emergence of the theory that is IS-based. Due to the dilapidation of this branch of behavioural theory, this research revives Consumption Value Theory (CVT) by Sheth et al. (1991), to create a set of mobile values that work as the antecedents to the mobile behaviour. Therefore, these studies that represented initial steps in understanding consumption value on mobile consumer behaviour would consider to examine all consumption values by Sheth et al. that possibly function independently, and contribute incrementally to the mobile apps usage. The conceptual framework of this study is displayed in Figure 1. Based on the framework, theoretical foundations for each component are developed. The framework developed by Sheth has been acknowledged as an influential underpinning theory in explaining modern mobile behaviour of the consumer (Candan et al., 2013; Aulia et al., 2016). Based on the above mentioned explanation, five consumption values include (i) functional, (ii) social, (iii) emotional, (iv) epistemic, and (v) conditional are examined.

Table 1: Overview of Some Studies Related to Mobile Apps in 5 years (2015-2019)

\begin{tabular}{|c|c|c|c|c|c|}
\hline No & Author(s) & Context & $\begin{array}{l}\text { Applied Theory/ } \\
\text { Base Model }\end{array}$ & $\begin{array}{l}\text { Predictor } \\
\text { Variable(s) }\end{array}$ & $\begin{array}{l}\text { Outcome } \\
\text { Variable (s) }\end{array}$ \\
\hline 1 & $\begin{array}{l}\text { Baptista and } \\
\text { Oliveira } \\
(2015)\end{array}$ & $\begin{array}{l}\text { Mobile } \\
\text { Apps For } \\
\text { Banking }\end{array}$ & UTAUT2 & $\begin{array}{l}\text { Performance } \\
\text { Expectancy, Effort } \\
\text { Expectancy, Social } \\
\text { Influence, Facilitating } \\
\text { Conditions, Hedonic } \\
\text { Motivation, Price } \\
\text { Value, Habit }\end{array}$ & $\begin{array}{l}\text { Behavioural } \\
\text { Intention, } \\
\text { Use } \\
\text { Behaviour }\end{array}$ \\
\hline 2 & $\begin{array}{l}\text { Hew, Lee, } \\
\text { Ooi \& Wei } \\
(2015)\end{array}$ & $\begin{array}{l}\text { Mobile } \\
\text { Apps }\end{array}$ & UTAUT2 & $\begin{array}{l}\text { Performance } \\
\text { Expectancy, Effort } \\
\text { Expectancy, Social } \\
\text { Influence, Facilitating } \\
\text { Conditions, Hedonic } \\
\text { Motivation, Price } \\
\text { Value, Habit } \\
\end{array}$ & $\begin{array}{l}\text { Behavioural } \\
\text { Intention }\end{array}$ \\
\hline 3 & Liu, 2015 & $\begin{array}{l}\text { Mobile } \\
\text { Apps For } \\
\text { Coupons }\end{array}$ & NA & $\begin{array}{l}\text { Perceived Value } \\
\text { Having Perceived } \\
\text { Money Savings, } \\
\text { Perceived } \\
\text { Convenience, } \\
\text { Perceived Enjoyment, } \\
\text { Perceived Fee, } \\
\text { Perceived Privacy, } \\
\text { Risk Dimensions, } \\
\text { Personal } \\
\text { Innovativeness And } \\
\text { Coupon Proneness }\end{array}$ & $\begin{array}{l}\text { Behavioural } \\
\text { Intention }\end{array}$ \\
\hline 4 & Groß (2015) & $\begin{array}{l}\text { Mobile } \\
\text { Apps For } \\
\text { Shopping }\end{array}$ & TAM & $\begin{array}{l}\text { Perceived Usefulness, } \\
\text { Perceived Ease Of } \\
\text { Use, Perceived } \\
\text { Enjoyment, Trust }\end{array}$ & $\begin{array}{l}\text { Attitude, } \\
\text { Behavioural } \\
\text { Intention } \\
\text { And Usage } \\
\text { Behaviour }\end{array}$ \\
\hline
\end{tabular}




\begin{tabular}{|c|c|c|c|c|c|}
\hline 5 & $\begin{array}{l}\text { Hsu \& Chen } \\
\text { (2016) }\end{array}$ & $\begin{array}{l}\text { Mobile } \\
\text { Apps for } \\
\text { Gaming }\end{array}$ & Perceived Values & $\begin{array}{l}\text { Playfulness, Access } \\
\text { Flexibility, } \\
\text { Connectedness, Good } \\
\text { Price, Reward }\end{array}$ & $\begin{array}{l}\text { In-App } \\
\text { Purchase } \\
\text { Intention, } \\
\text { Mobile } \\
\text { Game } \\
\text { Loyalty } \\
\end{array}$ \\
\hline \multirow[t]{2}{*}{6} & $\begin{array}{l}\text { Hsu \& Lin } \\
(2016)\end{array}$ & $\begin{array}{l}\text { Mobile } \\
\text { Apps }\end{array}$ & $\begin{array}{l}\text { Perceived Values } \\
\text { ABC Model of } \\
\text { Attitude }\end{array}$ & $\begin{array}{l}\text { Hedonic Value } \\
\text { Utilitarian Value } \\
\text { Attitude } \\
\text { Satisfaction } \\
\text { Stickiness } \\
\text { Social Influences } \\
\text { (Social Norms \& } \\
\text { Social Identification) }\end{array}$ & $\begin{array}{l}\text { Intention on } \\
\text { In-Apps } \\
\text { Purchase }\end{array}$ \\
\hline & $\begin{array}{l}\text { Hsiao, } \\
\text { Chang \& } \\
\text { Tang (2016) }\end{array}$ & $\begin{array}{l}\text { Mobile } \\
\text { Apps for } \\
\text { Social } \\
\text { Apps }\end{array}$ & $\begin{array}{l}\text { IS expectation- } \\
\text { confirmation }\end{array}$ & $\begin{array}{l}\text { Perceived Usefulness, } \\
\text { Perceived Enjoyment, } \\
\text { Social Ties, } \\
\text { Satisfaction, } \\
\text { Habit }\end{array}$ & $\begin{array}{l}\text { Continuance } \\
\text { Intention }\end{array}$ \\
\hline 7 & $\begin{array}{l}\text { Chopdar, } \\
\text { Korfiatis, } \\
\text { Sivakumar, } \\
\text { Lytras } \\
(2018)\end{array}$ & $\begin{array}{l}\text { Mobile } \\
\text { Apps For } \\
\text { Shopping }\end{array}$ & UTAUT2 & $\begin{array}{l}\text { Effort Expectancy, } \\
\text { Facilitating } \\
\text { Conditions, Habit, } \\
\text { Hedonic Motivation, } \\
\text { Performance } \\
\text { Expectancy, Price } \\
\text { Value, Social } \\
\text { Influence, Privacy } \\
\text { Risks, Security Risks }\end{array}$ & $\begin{array}{l}\text { Behavioural } \\
\text { Intention, } \\
\text { Use Of } \\
\text { Mobile } \\
\text { Shopping } \\
\text { Apps }\end{array}$ \\
\hline 8 & $\begin{array}{l}\text { Li, Su, Hu \& } \\
\text { Yao (2019) }\end{array}$ & $\begin{array}{l}\text { Mobile } \\
\text { Apps for } \\
\text { Festival }\end{array}$ & $\begin{array}{l}\text { Situational } \\
\text { Involvement } \\
\text { Theory }\end{array}$ & $\begin{array}{l}\text { Pleasure, Arousal, } \\
\text { Dominance, } \\
\text { Situational } \\
\text { Involvement }\end{array}$ & $\begin{array}{l}\text { Overall } \\
\text { Satisfaction }\end{array}$ \\
\hline 9 & $\begin{array}{l}\text { Noort and } \\
\text { Reijmersdal } \\
(2019)\end{array}$ & $\begin{array}{l}\text { Mobile } \\
\text { Apps For } \\
\text { Branding }\end{array}$ & $\begin{array}{l}\text { Transportation } \\
\text { Theory \& } \\
\text { Information } \\
\text { Processing } \\
\text { Models }\end{array}$ & $\begin{array}{l}\text { Information App, } \\
\text { Entertainment App, }\end{array}$ & $\begin{array}{l}\text { Cognitive } \\
\text { Brand } \\
\text { Response, } \\
\text { Effective } \\
\text { Brand } \\
\text { Response } \\
\end{array}$ \\
\hline 10 & $\begin{array}{l}\text { Lin, Guo, } \\
\text { Hsu, Yang, } \\
\text { Fu, Huang } \\
\text { (2019) }\end{array}$ & $\begin{array}{l}\text { Mobile } \\
\text { Apps for } \\
\text { Loyalty }\end{array}$ & TAM & $\begin{array}{l}\text { Mobile App } \\
\text { Perceived Usefulness, } \\
\text { Perceived Ease of Use }\end{array}$ & $\begin{array}{l}\text { Usage } \\
\text { Intention, } \\
\text { Users } \\
\text { Perception, } \\
\text { Satisfaction }\end{array}$ \\
\hline 11 & $\begin{array}{l}\text { Boyd, } \\
\text { Kannan, } \\
\text { Slotegraaf } \\
(2019)\end{array}$ & $\begin{array}{l}\text { Mobile } \\
\text { Apps for } \\
\text { Firm } \\
\text { Values }\end{array}$ & NA & $\begin{array}{l}\text { Branded Mobile Apps } \\
\text { Social Oriented } \\
\text { Feature, } \\
\text { Personal Oriented } \\
\text { Features, }\end{array}$ & $\begin{array}{l}\text { Firm Value } \\
\text { Abnormal } \\
\text { Returns } \\
\text { (ARs), } \\
\text { Calculated } \\
\text { Abnormal } \\
\end{array}$ \\
\hline
\end{tabular}




\begin{tabular}{|c|c|c|c|c|c|}
\hline & & & & $\begin{array}{l}\text { Transactional } \\
\text { Oriented Features }\end{array}$ & $\begin{array}{l}\text { Returns } \\
\text { (CARs), }\end{array}$ \\
\hline 12 & $\begin{array}{l}\text { Gao and } \\
\text { Waechter } \\
(2019)\end{array}$ & $\begin{array}{l}\text { Mobile } \\
\text { Apps For } \\
\text { Payment } \\
\text { Services }\end{array}$ & $\begin{array}{l}\text { TCE, TAM \& } \\
\text { ISS Model }\end{array}$ & $\begin{array}{l}\text { Perceived Benefits } \\
\text { Perceived } \\
\text { Convenience } \\
\text { Perceived System, } \\
\text { Information \& Service } \\
\text { Quality, } \\
\text { Perceived Uncertainty } \\
\text { \& Asset Specificity }\end{array}$ & $\begin{array}{l}\text { Initial Trust } \\
\text { Usage } \\
\text { Intention }\end{array}$ \\
\hline 13 & $\begin{array}{l}\text { Zhang, Lu } \\
\text { and Kizildag } \\
(2018)\end{array}$ & $\begin{array}{l}\text { Mobile } \\
\text { Apps for } \\
\text { Banking }\end{array}$ & TAM & $\begin{array}{l}\text { Perceived usefulness, } \\
\text { Ease of Use, } \\
\text { Enjoyment, Consumer } \\
\text { innovativeness, Trust } \\
\text { in the Bank, Privacy, } \\
\text { Reliability }\end{array}$ & $\begin{array}{l}\text { Attitude } \\
\text { Intention }\end{array}$ \\
\hline 14 & $\begin{array}{l}\text { Kim, Kim, } \\
\text { Choi and } \\
\text { Trivedi } \\
\text { (2017) }\end{array}$ & $\begin{array}{l}\text { Mobile } \\
\text { Apps For } \\
\text { Shopping }\end{array}$ & NA & $\begin{array}{l}\text { Online Experience, } \\
\text { Mobile Experience, } \\
\text { Breadth, } \\
\text { Frequency, } \\
\text { Length }\end{array}$ & $\begin{array}{l}\text { App } \\
\text { Possession } \\
\text { Mobile } \\
\text { Purchases }\end{array}$ \\
\hline 15 & $\begin{array}{l}\text { Rauschnabel, } \\
\text { Felix and } \\
\text { Hinsch } \\
\text { (2019) }\end{array}$ & $\begin{array}{l}\text { Mobile } \\
\text { Augmented } \\
\text { Reality } \\
\text { (AR-apps) }\end{array}$ & $\begin{array}{l}\text { AR Marketing } \\
\text { Theory }\end{array}$ & $\begin{array}{l}\text { Utilitarian Benefits, } \\
\text { Hedonic Benefits, } \\
\text { Augmentation Quality }\end{array}$ & $\begin{array}{l}\text { Changes in } \\
\text { Brand } \\
\text { Attitude }\end{array}$ \\
\hline
\end{tabular}

According to Sheth et al. (1991), CVT explains a multifaceted consumer choice on the notion of 'to buy or not to buy, to choose one type of product or service over another, and to choose one brand over another'. It entails a variety of value. Sheth et al. stated that, primarily, consumers are looking for the functional value of a product or service before progressing into the next phase of decision making. Functional value is defined as the benefit perceived or obtained from the functional and pragmatic quality of a product or service, whether a product can perform its functions, utilitarian, or physical purposes. Consumers' expectations may vary according to the products specifications, consumers' convenience, and personality traits (Aulia et al., 2016). A greater level of functional value would be expected to receive a higher mobile apps rating by the users who downloaded the app. Finkelstein, Harman, Jia, Martin, Sarro \& Zhang (2017) noticed the apps that offer instant messaging (IM), social networking, themes, and games are highly rated since they provide a considerable amount of utility to the users. The functional value of such apps provides a great benefit to the users, which encourage them to give a higher rating. Hence, this study theorises that the functional value would have a significant positive effect on the mobile apps' rating and proposes the following hypothesis:

$\mathbf{H}^{\mathbf{1}}$ : Mobile apps consumer perceived functional value to positively influence the mobile apps' rating.

Social value is described as the social benefits that are gained by a particular user when using the product or service. It is an image that is congruent with the norms of a consumer's friends or associates and/or with the social image the consumer wishes to project. The benefits may be positively or negatively related to the demographic profile, socio-economic status, and cultural (ethnic) group (Sheth et al., 1991). Boyd et al. (2019) affirmed that social value is driven by 
the influence of group membership and social networks, which can also be referred to as the reference groups. These groups engage a set of people with common values, attitudes, and behaviours. It is also stated that reference groups are considered to be an effective mechanism at persuading consumers to purchase or act according to a set of standards agreed by the group members through interpersonal communication and interaction by word of mouth. This value can be obtained when the users feel they are connected to other people who eventually influence their choices and actions (Aulia et al., 2016). It can be said that perceived social value to influence consumer behaviour through the apps' rating by instinctively prompting the users to give a high rating to the apps that play a symbolic role in their social context (Rauschnabel et al., 2019). As a result, this study proposes the following hypothesis:

$\mathbf{H}^{2}$ : Mobile apps consumer perceived social value, positively influences the mobile apps' rating.

Emotional value is related to various affective states, which can be positive (for example, confidence or excitement) or negative (for example, fear or anger). Emotions are integral to the intimate relationship between smartphone devices and their users (Ding \& Chai, 2015). Although past studies have discovered the impact of emotions on apps usage (Cocosila \& Igonor, 2015; Wu, Shu-Hua \& Kang-Ping, 2017), limited focus has been given to the influence of emotional value on the apps rating and apps cost. The investigation of emotional value intended to capture the users' intention to purchase an app, a product, or a service. They described this value, as the state of the mood or feelings associated with the usage of the app. Candan et al. (2013) elaborated that an emotional value reflects the benefit as a result of the emotional and sensational circumstance. While Xiao and Kim (2009) noted that emotional value is also related to the consumers' reactions concerning a product or service. These reactions can be posited as the consumers' actions, such as providing reviews and feedback, rating the mobile apps, and recommending it to other users (Wu et al., 2017). The apps' rating is crucial to marketers as it represents the users' impressions that can influence online store visits, which translates to the purchase behaviour (Baik, Venkatesan, \& Farris, 2014). The discussions have resulted in the following hypothesis:

$\mathbf{H}^{\mathbf{3}}$ : Mobile apps consumer perceived emotional value, positively influences the mobile apps' rating.

On the other hand, epistemic value refers to the act of curiosity, desire for knowledge, or novelty seeking in products or services (Aulia et al., 2016). This value is perceived or obtained from the product or service in which the benefits from the value are expected to meet the users' desire and need for innovation (Candan et al., 2013). Sheth et al. (1991) asserted that users with epistemic value tend to try new products or services and are most likely to switch brands. The search for novelty and diversity are the motives that compel consumers to habitually change their purchase behaviour (Singh \& Zolkepli, 2018). Candan et al. (2013) also indicated that innovative customers, the ones with high epistemic value, are prone to pay a high price to use a new product or service. It is known that new products are normally introduced at a higher price. Chopdar et al. (2018) described that higher perceived epistemic value leads to a greater intention to purchase and use a particular product or service while Palomba et al. (2015) revealed that new apps are more likely to attract informative reviews, which can lead to an increase in the apps' rating; this can be hypothesised as follows:

$\mathbf{H}^{4}$ : Mobile apps consumer perceived epistemic value, positively influences the mobile apps' rating. 
The existing research on perceived values mentioned that conditional value occurs as a result of changes in consumers' buying preferences in certain situations, such as seasonal situations, once in a lifetime events, or unplanned and emergency situations (Sheth et al., 1991; Candan et al., 2013). It reflects the fact that some market choices are contingent on the situation or set of circumstances faced by the consumers. Gao \& Waechter (2013) explicated that the conditional value initially exists to satisfy temporary or situational needs that can impact the users' choice. Hence, this study proposed that:

$\mathbf{H}^{\mathbf{5}}$ : Mobile apps consumer perceived conditional value, positively influences the mobile apps' rating.

\section{Mediation Effects of Mobile Apps Rating and Cost on Apps Usage}

According to Liu, Au, and Choi (2014), a mobile app is defined as software that authorises the user to perform a specific task on a range of portable devices, such as smartphones and tablets. Mobile apps were originally developed for functional purposes, such as e-mail, schedule updates, calendars, and weather prediction (Hsiao et al. 2017). As the technology became smarter, the functions of apps were extended to games, banking, payments, order-tracking, and location-based services to meet the huge growth of coverage, mass demand, and advanced mobile technology (Hew, Lee, Ooi, \& Wei, 2015; Tarute et al., 2017). Accordingly, the extensive use of smartphones has motivated scholars to conduct studies on mobile applications and unearth the motives that influence users to engage with mobile apps (Jain \& Viswanathan, 2015; Carter \& Yeo, 2016; Wu et al., 2017). Although several studies related to perceived values and mobile apps (Dovaliene et al., 2015; Hsiao \& Chen, 2016; Marakanon \& Panjakajornsak, 2016; Zhang et al., 2017) have been conducted, previous results are fragmented in terms of the dimensions of the perceived values, and the implications for practitioners remain inconclusive as explained in Table 1. Also, limited knowledge concerning the relationship between the apps rating, cost, and their relations with usage has been acquired.

Mobile apps are applications designed to run natively on mobile devices like smartphones and tablets, sharing the same interface characteristics as the host operating system. In the two largest app repositories that is App Store (for iOS) and Google Play (for Android), there are a multitude of apps enabling marketing promotional activities such as discount and daily deal apps, price comparison apps, digital wallets and payment apps, branded apps from retailers and many more (Kim et al., 2017). Contextualizing this research inquiry to rating and cost of the apps as the mediating factor driving usage behaviour, research to date has focused on adoption and use of various types of mobile apps, but little attention has been given explicitly to the effect of rating and cost pertaining to the mobile behaviour as depicted in Table 1. Taylor and Levin (2014) reported that the design elements of an app, affect user interest as well as the intention to purchase. Zhao and Balague (2015) propose that personalization and customization are critical to selling products in mobile commerce apps. Previous studies on mobile interfaces have mostly focused on improving mobile app usability and visibility (Biel, Grill, \& Gruhn, 2010), assessed the influence of demographic, psychological and behavioral factors on adoption of mobile apps (Verkasalo, Lopez-Nicol, Molina-Castillo, \& Bouwman, 2010) as well as the influence of user reviews regarding their performance and acceptance (Huang \& Korfiatis, 2015).

Furthermore, Filkenstein et al. (2017) investigated the relationship between price, rating, and popularity in the Blackberry World App Store. The findings reveal that apps that need to be 
purchased or non-free apps are inclined to have a lower rating. Even though the analysis was conducted for Blackberry apps, the viability of the results, especially the distribution of prices and ratings, comprehensively extends to all apps. It was also discovered that there is a strong connection between apps rating and popularity (i.e., the rank of downloaded apps). Roma, Zambuto, and Perrone (2016) mentioned that the most downloaded apps have a high rating, but the trend only applies to free apps. The users are not interested in using non-free apps, including the in-app purchase platform because they will opt for other apps with a similar function at no cost (Bhave et al., 2013). Moreover, users perceive a certain value intending to gain satisfaction from the use of particular apps, and they are prone to rate them higher and continue using those apps. As a result, other users who are aware of the high rating will tend to download the apps, which, in turn, can lead to continuity in using mobile apps. Hence, this study suggests the following hypotheses:

$\mathbf{H}^{\mathbf{6}}$ : Mobile apps' rating is positively related to mobile apps cost.

$\mathbf{H}^{7}$ : Mobile apps' rating determined mobile apps usage.

Besides, there are limited studies on mobile apps relating to apps rating and apps cost. Previous studies have found little evidence for the relationship between the apps rating and cost, but the studies have identified that the significance of popularity (most downloaded apps), the role of the distribution platform, trust, and interest in the apps are statistically related to the continuance of apps usage (Roma et al., 2016; Filkenstein et al., 2017; Wu et al., 2017). In particular, Filkenstein et al. (2017) revealed that non-rated apps tend to be less popular than the rated ones regardless of the apps' cost. The findings note that users are most likely to purchase an app if the rating and popularity (by looking at the most downloaded apps) are high. This scenario shows that users will continue to use the apps even if they have to purchase them, which is in line with Wu et al. (2017) who agreed that users are inclined to purchase paid apps as long as they trust the apps. Trust is prevalent when users have high expectations of the service providers and assume that the service providers are trustworthy and reliable (Castaldo, Premazzi, \& Zerbini, 2010). It is noted that users expect quality products or services that can satisfy their desires. As a result, they will be willing to purchase mobile apps regardless of the cost. Wu et al. (2017) also noted that trust signifies commitment, and therefore, influences the users' willingness to maintain their relationship with the apps, which indicates the loyalty, adherence, and continued usage intention. On the other hand, Roma et al. (2016) and Filkenstein et al. (2017) mentioned that the reverse causality between apps cost and apps rating shows that paid apps tend to have lower ratings as free apps have higher ratings. Nevertheless, no study investigates the role of apps cost as a mediator between apps rating and apps usage. As a result, this study developed the following hypotheses:

$\mathbf{H}^{\mathbf{8}}$ : Mobile apps cost determined mobile apps usage.

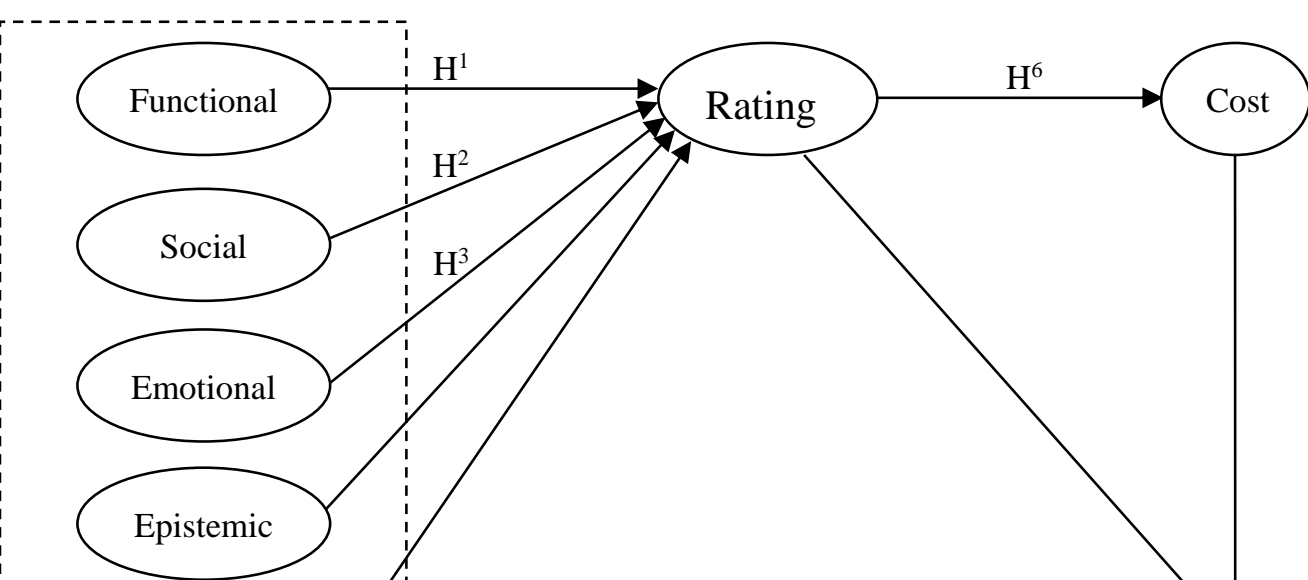


Figure 1 Research Framework

\section{Methodology}

The data for this study were collected using an online-based questionnaire via Survey Monkey platform with non-probability convenience sampling between March and April 2017. Participants were motivated with a token (in the form of vouchers) for a complete response. Subject recruitment was performed from a consumer panel, which was sourced from a market research company in Malaysia. The time taken to complete the questionnaire was about 15 minutes. The items for each construct of the model were measured on a five-point Likert Scale (from strongly disagree to strongly agree), and each construct was presented on a separate page to avoid confusion. The questionnaire was distributed in English, considering that the participants in the consumer panel have participated in other English-speaking market research studied, language proficiency was not considered as an issue.

Two level randomization was used that includes the order of constructs and order of items to avoid endogeneity and impulsive responses. Those who failed the attention check were automatically excluded from the system, and their responses were discarded. Multicollinearity and common method bias were assessed and found not to be a problem. The complete measurement items with the respective sources of items are shown in Table 2. As suggested by Hew et al. (2015), this study includes more items from the original items specified in order to have a complete measurement procedure. All the methodological remedies suggested by MacKenzie and Podsakoff (2012) were followed, such as explaining the importance of questions and clarifying doubts as well as ensuring anonymity and confidentiality in all stages of the survey.

In total, 400 questionnaires were distributed online, and 392 valid responses were received. The completed questionnaires yielded a response rate of $98 \%$. In general, the respondents are between 20 and 39 years old (44.5\%), and are always on their mobile apps (48.2\%). The distribution of female and male respondents is at $52.3 \%$ and $47.8 \%$, respectively, which indicates that the majority of mobile apps users are female. The sample can be considered to be a fair representation of the general mobile apps users based on gender differences (Hsiao et al., 2016). The majority of the respondents own at least one smartphone. There is a slight difference between the ownership of Samsung and Apple smartphones in which $38.3 \%$ own Samsung smartphones, and 34.7\% own Apple smartphones; the remaining 27\% of the respondents own other brands, such as Asus, Sony, HTC, Lenovo, Alcatel, Xiaomi, Moto G, LG, Huawei, Vivo, One Plus, Nokia, Oppo, ZTE, Ninetechnology, MI, Meizu, and Alcatel. 
The Harman single factor test was performed to ensure that there was no Common Method Variance in the survey. The results showed that $37.74 \%$ variance was explained by a single factor, which was less than the threshold level of $50 \%$ for the total explained variance (Zolkepli, Kamarulzaman, \& Kitchen, 2018). The results were analysed using a single factor constraint of factor analysis in SPSS. All the constructs and items were adapted from previous studies to suit the context. The measurements in this study were taken from previous studies related to perceived value, mobile apps rating, mobile apps cost, and mobile apps usage. There were 32 items for the perceived value that were adapted from Sweeney and Soutar (2001), Maghnati and Ling (2013), and Wang, Liao, and Yang (2013). The construct for the mobile apps' rating was measured using six items, and there were five items for mobile apps cost. Both of these constructs were adapted from Hsu and Lin (2015). The dependent variable, which is mobile apps usage, was adapted from Zolkepli and Kamarulzaman (2015) using six items. The reliability of the questionnaire was validated from the pilot test, which was administered to 100 respondents in January 2017. The initial data from the pilot test were used to conduct factor analysis, and no amendments were done since the factor loadings of the items were higher than 0.7. The final results of the pilot test showed that the instrument had acceptable reliability and validity. As a result, the questionnaires and the items for the measurement were retained for the actual data collection.

Table 2: Quality of The Measurement Items

\begin{tabular}{|l|l|}
\hline Code & \multicolumn{1}{l|}{ Items } \\
\hline $\begin{array}{l}\text { Functional Values }(\mathrm{FV})-\alpha(0.9280), \text { Mean }(3.91-4.09), \text { SD }(0.823-0.790), \text { Factor } \\
\text { Loading }(0.7753-0.8977)\end{array}$ \\
\hline FV1 & My mobile apps fulfil my needs for using a smartphone \\
\hline FV2 & My mobile apps have an acceptable standard of quality \\
\hline FV3 & My mobile apps offer consistent quality \\
\hline FV4 & My mobile apps are made for my purpose \\
\hline FV5 & My mobile apps are well constructed \\
\hline FV6 & My mobile apps performed consistently \\
\hline FV7 & My mobile apps can be used for a long time \\
\hline Social Values (SV) - $\alpha(0.9323)$, Mean (3.67 - 3.92), SD (0.878 - 1.057), Factor Loading \\
(0.7888 -0.9120$)$ \\
\hline SV1 & Using mobile apps make me feel accepted by others \\
\hline SV2 & Using mobile apps gives a good impression on me \\
\hline SV3 & Using mobile apps give me social approval \\
\hline SV4 & Using mobile apps improve the way I am perceived \\
\hline SV5 & Through my mobile apps, it lets me express myself freely \\
\hline SV6 & $\begin{array}{l}\text { Through my mobile apps, it lets me fit in a group of people that share the same } \\
\text { interests }\end{array}$ \\
\hline SV7 & Through my mobile apps, I find a new way to socialize \\
\hline Emotional Values (EV) - $\alpha(0.9638)$, Mean (3.99 - 3.82), SD (0.783 - 0.893), Factor \\
Loading (0.7665 - 0.8892) \\
\hline EV1 & Using mobile apps is interesting \\
\hline EV2 & Using mobile apps makes me feel good \\
\hline EV3 & Using mobile apps gives me pleasure \\
\hline EV4 & Using mobile apps makes me feel relaxed \\
\hline EV5 & Using mobile apps is enjoyable \\
\hline EV6 & Using mobile apps makes me cheerful \\
\hline
\end{tabular}




\begin{tabular}{|c|c|}
\hline EV7 & Using mobile apps is rewarding \\
\hline EV8 & Using mobile apps gives me a sense of satisfaction \\
\hline EV9 & Using mobile apps gives me contentment \\
\hline EV10 & Using mobile apps keeps me at leisure \\
\hline EV11 & Using mobile apps is cool \\
\hline EV12 & Using mobile apps is full of excitement \\
\hline \multicolumn{2}{|c|}{$\begin{array}{l}\text { Epistemic Values (EPV) }-\alpha(0.9210), \text { Mean }(3.86-3.96), \text { SD }(0.766-0.885), \text { Factor } \\
\text { Loading }(0.8209-0.8730)\end{array}$} \\
\hline EPV1 & Mobile apps enable me to test the new technologies \\
\hline EPV2 & Mobile apps make experiment with new ways of doing things \\
\hline EPV3 & Mobile apps arouse my curiosity \\
\hline EPV4 & Mobile apps are aesthetically appealing \\
\hline EPV5 & Mobile app design is interesting \\
\hline EPV6 & Mobile apps are trendy \\
\hline \multicolumn{2}{|c|}{$\begin{array}{l}\text { Conditional Values }(\mathrm{CV})-\alpha(0.8983), \text { Mean }(3.95-4.08), \mathrm{SD}(0.772-0.815), \text { Factor } \\
\text { Loading }(0.7973-0.8860)\end{array}$} \\
\hline CV1 & $\begin{array}{l}\text { When in an unfamiliar environment, mobile apps help me to identify my current } \\
\text { location and further direction }\end{array}$ \\
\hline CV2 & $\begin{array}{l}\text { No matter what time or place is, using mobile apps assist me in completing my } \\
\text { task }\end{array}$ \\
\hline CV3 & $\begin{array}{l}\text { When I am in uncertain circumstances and need more information to facilitate the } \\
\text { decision, mobile apps can provide related real-time information (e.g., taxi arrival, } \\
\text { weather, stocks) to help me make the decision }\end{array}$ \\
\hline CV4 & The feature assortment that embedded in the mobile apps fit my needs \\
\hline CV5 & I feel a sense of connectedness with the world \\
\hline \multicolumn{2}{|r|}{$\begin{array}{l}\text { Mobile Apps Rating (RATE) }-\alpha(0.9441) \text {, Mean }(3.92-3.99), \text { SD }(0.828-0.795) \text {, Factor } \\
\text { Loading }(0.8908-0.9223)\end{array}$} \\
\hline RATE1 & The mobile apps that I used are highly rated \\
\hline RATE2 & The mobile apps that I used have good ratings on websites \\
\hline RATE3 & The mobile apps' rating shows apps trustworthiness \\
\hline RATE4 & The mobile apps' rating shows apps credibility \\
\hline RATE5 & The mobile apps' rating is useful \\
\hline RATE6 & The rating helps me to understand the quality of mobile apps \\
\hline \multicolumn{2}{|r|}{$\begin{array}{l}\text { Mobile Apps Cost (COST) }-\alpha(0.9274), \text { Mean }(3.69-3.80), \text { SD }(0.840-0.987), \text { Factor } \\
\text { Loading }(0.7592-0.9288)\end{array}$} \\
\hline COST1 & The price of mobile apps is economical \\
\hline COST2 & The mobile apps are good for the current price level \\
\hline COST3 & The mobile apps are reasonably priced \\
\hline COST4 & The price of mobile apps gives value for money \\
\hline COST5 & Because the mobile apps fulfil my needs, I do not mind to purchase the apps \\
\hline \multicolumn{2}{|c|}{$\begin{array}{l}\text { Mobile Apps Usage (USE) - } \alpha(0.9364), \text { Mean }(3.83-4.01), \text { SD }(0.781-0.854), \text { Factor } \\
\text { Loading }(0.7610-0.8724)\end{array}$} \\
\hline USE1 & My mobile apps usage has substantially changed my life \\
\hline USE2 & I intend to use more mobile apps in the near time \\
\hline USE3 & I would use mobile apps without hesitation to satisfy my needs \\
\hline USE4 & Using mobile apps makes my life easier \\
\hline USE5 & I receive a lot of benefit from my mobile apps \\
\hline
\end{tabular}

Note: $\alpha$-Alpha Value, SD - Standard Deviation 


\subsection{Analysis Method}

This study employed PLS-SEM to simultaneously explain and predict the structural relationships among the independent variables, mediator, and the dependent variable to test the proposed research model (Ringle, Wende, \& Becker, 2015). The analysis was performed by following the two-step approach, as recommended by Anderson and Gerbing (1988). The reliability and validity of the measurement model were assessed using the recommended procedural remedies, followed by the structural model assessment and hypotheses testing using a bootstrapping approach. The settings recommended by Hair, Hult, Ringle \& Sarstedt (2017) were used in running the PLS-algorithm and as such, the path-weighting scheme was selected to follow a standardized data metric. In addition, the value of the maximum number of iterations was 300 , the initial value for all outer weights was set equal to one, and the stopping criteria value was $<10^{-6}$.

\section{Results}

\subsection{Measurement Model Evaluation}

In this stage, four assessments were examined for convergent and discriminant validity tests that include, (i) factor loadings, (ii) Average Variance Extracted (AVE), (iii) Composite Reliability (CR), and (iv) Discriminant Validity. By signifying the indicator loadings, all items were ranged between 0.76 and 0.93 , which exceeded the recommended value of 0.708 suggested by Hair et al. (2017). The AVE values were greater than the 0.5 thresholds, ranging from 0.70 to 0.82 . Next, the CR values ranged between 0.93 and 0.97 , which exceeded the recommended value of 0.70 (Hair et al., 2017). The high values for CR showed that there was high internal consistency. Overall, the measurement model expressed that the instrument had satisfactory convergent validity and discriminant validity.

Table 3 Discriminant Validity Analysis \& Correlation

\begin{tabular}{lllllllll}
\hline & FV & SV & EV & EPV & CV & RATE & COST & USE \\
\hline FV & $\mathbf{0 . 8 9 8 3}$ & & & & & & & \\
SV & 0.7385 & $\mathbf{0 . 9 2 7 4}$ & & & & & & \\
EV & 0.7843 & 0.7691 & $\mathbf{0 . 9 6 3 8}$ & & & & & \\
EPV & 0.8061 & 0.7684 & 0.8585 & $\mathbf{0 . 9 2 1 0}$ & & & & \\
CV & 0.7626 & 0.6934 & 0.7215 & 0.7440 & $\mathbf{0 . 9 2 8 0}$ & & & \\
RATE & 0.7591 & 0.7802 & 0.7507 & 0.7477 & 0.7201 & $\mathbf{0 . 9 4 4 1}$ & & \\
COST & 0.6529 & 0.6941 & 0.8111 & 0.7643 & 0.6575 & 0.6877 & $\mathbf{0 . 9 3 2 3}$ & \\
USE & 0.8063 & 0.8354 & 0.8231 & 0.7806 & 0.7587 & 0.7553 & 0.6607 & $\mathbf{0 . 9 3 6}$ \\
\hline
\end{tabular}

Note: Diagonals (in bold) represent the squared root of AVE while the other entries represent the correlations

\subsection{Analysis of the Structural Model}

The satisfactory measurement models enabled this study to progress to the next step of the structural analysis. The adequacy of the structural model in PLS-SEM was evaluated based on various criteria namely: (i) the level of significance of path coefficients, (ii) the coefficient of determination $\left(\mathrm{R}^{2}\right)$, and (iii) predictive relevance $\mathrm{Q}^{2}$ value of the path model (Hair et al., 2017). The bootstrap resampling procedure with 5000 samples was applied to evaluate the statistical 
significance of path coefficients. The PLS algorithm was used to obtain the coefficient size. Table 4 shows the findings from the hypotheses testing.

Table 4 Structural Analysis Results

\begin{tabular}{|c|c|c|c|}
\hline Path & $\beta$ value & $t$-value & Decision \\
\hline $\mathrm{FV} \rightarrow \mathrm{RATE}$ & 0.1986 & $3.213 * *$ & Supported \\
\hline $\mathrm{SV} \rightarrow \mathrm{RATE}$ & 0.1534 & $1.830 *$ & Supported \\
\hline $\mathrm{EV} \rightarrow \mathrm{RATE}$ & 0.1576 & $1.704 *$ & Supported \\
\hline $\mathrm{EPV} \rightarrow \mathrm{RATE}$ & 0.1068 & 1.217 & Not supported \\
\hline $\mathrm{CV} \rightarrow \mathrm{RATE}$ & 0.2984 & $3.326 * *$ & Supported \\
\hline RATE $\rightarrow$ COST & 0.7801 & $27.593 * *$ & Supported \\
\hline \multicolumn{4}{|c|}{ Manifestation and Impact of the Mediation } \\
\hline RATE $\rightarrow$ USE & 0.261 & $4.520 * *$ & Supported \\
\hline $\mathrm{COST} \rightarrow \mathrm{USE}$ & 0.633 & $12.066 * *$ & Supported \\
\hline $\mathrm{RATE} \rightarrow \mathrm{COST} \rightarrow \mathrm{USE}$ & 0.494 & $12.344 * *$ & Supported \\
\hline Base Model & \multicolumn{3}{|c|}{$\mathrm{R}^{2}=0.726$} \\
\hline $\mathrm{R}^{2}$ With RATE & \multicolumn{3}{|c|}{$R^{2}=0.674$} \\
\hline $\mathrm{R}^{2}$ With COST & \multicolumn{3}{|c|}{$\mathrm{R}^{2}=0.609$} \\
\hline
\end{tabular}

\subsection{Variance Explained, Predictive Relevance and Effect Size}

This study has three endogenous constructs. First, the $\mathrm{R}^{2}$ value for the mobile apps' rating is at 0.674 , which suggests that the perceived value explained $67 \%$ of the variance in the mobile apps' rating. Second, the $\mathrm{R}^{2}$ value for the mobile apps cost is at 0.609 , suggesting that $61 \%$ of the variance was explained by the perceived value and mobile apps rating. Lastly, the $\mathrm{R}^{2}$ value for mobile apps usage is at 0.726 , which suggests that the perceived value, mobile apps rating and mobile apps cost explained $73 \%$ of the variance in mobile apps usage.

By referring to the hypotheses of the perceived values, the findings showed that all the values have a significant positive effect on the mobile apps' rating except for EPV. Thus, $\mathrm{H}^{1}, \mathrm{H}^{2}, \mathrm{H}^{3}$, and $\mathrm{H}^{5}$ are supported by the proposed model. Moreover, the analysis revealed that RATE has a positive direct relationship with the COST, which supports $\mathrm{H}^{6}$. Next, the $f^{2}$ is calculated to examine the impact of the exogenous constructs on the endogenous constructs (Hair et al., 2017). Using the formula by Hair et al. (2017), which is $f^{2}=\left(\mathrm{R}^{2}\right.$ included $-\mathrm{R}^{2}$ excluded $) /(1-$ $\mathrm{R}^{2}$ included), the same formula was also used to compute $Q^{2}$. In evaluating the model's predictive relevance, the $Q^{2}$ was conducted using the blindfolding procedure. As a reference, the values of $f^{2}$ and $Q^{2}$ that ranged from 0.02 to 0.014 are considered weak, 0.15 to 0.34 are moderate, and above 0.35 are strong (Hair et al., 2017). Table 5 shows the results of $f^{2}$ and $Q^{2}$.

Table 5 Results of $f^{2}$ and $Q^{2}$

\begin{tabular}{lcccc}
\hline Endogenous & \multicolumn{2}{c}{$f^{2}$ value } & \multicolumn{2}{c}{$Q^{2}$ value } \\
FV & RATE & USE & RATE & USE \\
SV & 0.0428 (Small) & - & 0.0208 (Small) & - \\
CV & 0.0214 (Small) & - & No effect & - \\
& 0.0734 (Small) & - & 0.0354 (Small) & -
\end{tabular}


Insinuating Table 5, the FV, SV, and $\mathrm{CV}$ are found to have small predictive values on RATE $\left(f^{2}=0.0428, f^{2}=0.0214, f^{2}=0.0734\right)$, while the EV and EPV showed no effect. However, in predicting USE, COST has a large effect size $\left(f^{2}=0.5620\right)$. For the predictive relevance $\left(Q^{2}\right)$, only two dimensions of the perceived values can predict RATE with small effects, which are $\mathrm{FV}$ and $\mathrm{CV}\left(Q^{2}=0.0208, Q^{2}=0.0354\right)$, whereas COST has a medium predictive relevance for USE $\left(Q^{2}=0.2257\right)$. For evaluating the predictive power of the model, the cross-validated redundancy measures of $Q^{2}$ was applied (Hair et al., 2017) and were found to have adequate predictive relevance. As can be seen in Table 5 the reported $Q^{2}$ values are lower than 0.35 suggesting medium predictive relevance as with the prescribed cut-off (Hair et al., 2017). Therefore, the research model has substantial predictive power in explaining USE.

\subsection{Mediation Model}

This study hypothesised that the COST mediates the relationship between perceived values, RATE, and USE. Therefore, the mediation effect was examined using the procedures by Hayes (2009). According to Hayes (2009), the indirect effects do not necessarily become a mediator, and the absence of a direct effect between the independent variable and the dependent variable does not reject the mediation effect. As a result, bootstrapping was suggested as the strategic approach.

Referring to Table 2, RATE showed a positive effect on USE $(\beta=4.520, \mathrm{p}<0.01)$ and COST has a significant direct effect on the USE $(\beta=12.066, \mathrm{p}<0.01)$. Thus, $\mathrm{H}^{8}$ is supported. The bootstrapping results showed that the indirect effect of RATE on USE through COST is significant with a $t$-value of 12.344. According to Preacher and Hayes (2004), the indirect effect of 0.494 and the confidence interval $(\mathrm{LL}=0.415, \mathrm{UL}=0.572)$ did not straddle a 0 , thereby indicating that there is a mediation effect. Thus, it can be concluded that the mediation effect is statistically significant for the relationship between RATE and USE with COST as the mediator. Despite the value placed on the mobile app, the mediator significantly affect the entire usage behaviour of the mobile consumer.

\section{Discussion}

Mobile apps are one of the effective monetization strategies for the marketer, and the commercial success of mobile apps depends largely on its usage and continuous usage. This study examined the effect of perceived values on mobile apps usage and tested the mediation effect of mobile apps rating and cost on the overall formation of mobile behaviour. Findings and implications are discussed as follows:

First, the proposed model is found to accurately predict the effect of perceived apps values on mobile consumer behaviour. This study recommends a framework that integrates perceived values, cost, and rating that can be employed to assess the antecedents of mobile apps usage behaviour. It also develops the directional and causality relationship between mobile apps' perceived values, apps rating, and apps cost. Out of five values tested, four values were found to have a significant effect on the apps rating and entire mobile behaviour, thus emphasising that mobile apps users are thoughtful in the values element the apps marketer positions in the apps. However, epistemic values were found not to be important that signalled some amusement and enjoyment element (that relates very much to the experience) to be missing. Inclusively, this study proposed eight hypotheses. 
It also confirms that the mobile apps' rating is highly dependent on the perceived values in terms of the mobile apps' functional, social, emotional, and conditional values. Among all, the conditional value has the highest correlation, followed by functional, emotional, and social. The results indicate that the conditional value, also seen as the trend at the moment, plays a significant role in determining the mobile apps' rating, which contradicts previous studies that tested conditional value on a different context setting. In the previous studies, the functional value was believed to be the key influence in motivating the consumers' decisions making (Sheth et al., 1991; Wang et al., 2013). However, this study reveals that the mobile apps' rating will be higher if the apps are hyped and trending (conditional value), for example, like PokemonGo. According to Martin (2019), PokemonGo has generated a revenue of 1.2 billion and was downloaded approximately 752 million times. About 5 million active users are playing PokemonGo across the globe at this moment. The hypothesized model expected a certain degree of influence of apps rating and cost on user behaviour. This model is in contrary to Kim et al. (2016) that found otherwise. Due to the fact that Kim used TAM to underpin the research, the respondents ought to find cost as not an influential element. Whereas in this study, due to the particularity of apps price (which deemed different based on the Android and iOS), it highlighted that rating and cost works differently from perceived value element, that explains the variation in the result. The perception about the rating and cost of the apps, were likely to vary according to mobile user economic tendencies and the apps' marketing strategy (that differ between Android and iOS) rather than the value element based on the five value factor proposed by Sheth et al. (1991).

The functionality of the mobile apps come in second place in terms of values, followed by emotional and social values. From the social value perspective, Carter \& Yeo (2016) emphasized that smartphone users tend to use mobile apps that are favoured by their peers, considering that the apps can fulfil their social needs. They predominantly used mobile apps because of the social influence of the other social group. Also, the mobile apps' rating will be higher if the smartphone users enjoyed the apps (Verkasalo et al. 2010; Zolkepli, 2016). It was found that the majority of the respondents were in the range of 20 to 39 years old, which shows that the average younger cohort depend on their gadgets and the Internet in their daily life. Nicholas (2014) mentioned that the young generation is also known as the "Google Generation" and was born in 1993 and onwards. This generation was brought up in the Internet world and also the users of mobile devices or apps. They prefer to use mobile apps as a platform with their circle of friends, who influence them into preferring certain mobile apps.

The epistemic value in this study refers to the extent to which the apps can arouse curiosity, and satisfy the desire for knowledge and novelty experience, which have been proven to be irrelevant in determining the mobile apps' rating. This result has proven that smartphone users are not in favour of any analytical or complicated mobile apps, which increase the likelihood of them giving a low rating. This result represents the respondents who are mostly from the much younger generation, that refuse to use the apps to unearth information and prefer the interactivity of the apps for pleasure seeking and personalisation for regular usage (Summerfield, 2012). Chen et al. (2017) mentioned that it is important to understand the market segments, potential customers, and their perceived values as this can help developers in customising the products and services to satisfy the users' personalised preferences.

Besides, it was also found that consumers are willing to pay for mobile apps that have reasonable ratings. It has been verified that the mobile apps cost mediates the relationship between mobile apps rating and apps usage. However, a study by Finkelstein et al. (2017) found 
no association between apps cost and apps rating in the Blackberry World App Store. The study only found that several features have a moderate correlation with apps cost. This finding validates this study in that apps' cost plays a significant role in determining the apps' usage among users, which closes the gap concerning the significant role of mobile apps cost in mediating apps rating and apps usage. The findings from this study have verified the importance of the perceived values in influencing the mobile apps rating and the significance of cost to intensify the mobile apps usage. Businesses can benefit from this relationship to design operative mobile apps for users' continuous usage.

\section{Conclusions and Limitations}

Smartphone users spend more time using a mobile phone than other mobile services, even more than accessing the Web via the computer. This phenomenon implies the dramatically rapid growth of mobile apps across the market and geography. Mobile apps are already influential, not only in the mobile industry, but also in the new media industry as a whole. Nonetheless, these apps have received little attention within the marketing communication, especially pertaining to integrated marketing communication. Mobile apps are now becoming one of the digital marketing tools, where apps marketing is slowly booming with many apps designed to target specific segments, needs and tasks. Hence, this study provides both theoretical and practical implications for researchers, smartphone users, marketers, and app developers.

Although other researchers have widely examined the perceived values, previously, no study explained how these values influence the behaviour of the mobile consumer. Furthermore, there was also limited reference concerning how perceived values affect the usage, and how these values were stimulated by the rating and cost of the apps. Previous studies found that users tend to consider the rating system before deciding to engage with particular apps (Filkenstein et al., 2017; Tarute et al., 2017). To address this gap in the literature, this study examines the relationship between the perceived values, apps rating and cost, hence forming an integrated framework that can explain why mobile consumers formed a specific behaviour towards the apps, and through this, it gives understanding on the role of apps rating and cost in the formation of mobile behaviour on apps.

Overall, the findings reveal that the epistemic value is the only value that does not have a significant influence on the apps' rating. It was found that conditional value has the strongest link with the apps' rating, followed by the functional, social, and emotional values. These findings provide insightful facts in that users who perceive conditional and functional values are prone to review apps with a higher rating. For the role of apps cost, it was discovered that other than a satisfactory $\mathrm{R}^{2}(61 \%)$, the effect size $\left(f^{2}=0.562\right.$ : large $)$ and the predictive validity $\left(q^{2}=0.226\right.$ : medium $)$ of the apps' cost are considered to be strong indicators that apps cost should be given more focus in future research. The results show that the conditional value has the highest correlation, which suggests that users give higher value and rating to apps that are trending. Users are also willing to pay for apps that have a higher rating. This result also suggests that smartphone users are not in favour of analytical or complicated mobile apps. Moreover, this result will serve as a valuable clue to how marketers, content providers, and managers should approach their product.

In order to deepen the research on mobile apps and mobile marketing communication, it is imperative for future studies to explore the reason underlying the insignificant of epistemic value, and why it does not affect mobile apps usage like it does in other product consumption. The epistemic element of the mobile apps' desirability and curiosity was presumed not to exist 
so much in the development of the apps. This study reveals an interesting area that mobile apps' developers and marketers could investigate more. The missing part of this value in mobile apps development can hinder the user from downloading some apps, especially those that were made for the specific purpose like game, e-commerce, festival and tourism. Epistemic value is very close to the experience that the user gains in their journey with the apps. Does app's activities such as augmented experience, immersive experience and adaptive feedback, (Suarez, Specht, Prinsen, Kalz and Ternier, 2018) be examined further? If epistemic values is deemed insignificant, it indicates that the experience the mobile apps developer includes in the apps is probably minimal or none.

In general, this study is subject to certain limitations; thus, the findings should be interpreted with caution. First, the sample of this study is limited to Malaysian apps' users. Hence, future studies should include other countries, and probably the technological and culture element could play a role in determining the consumption values. It is also suggested that readiness and inclusiveness be taken into account when studying values in order to obtain a more comprehensive apps usage result. Second, the locality of this research is restricted to apps users in Malaysia. So, it is advised to collect samples from other countries and diverse cultures to obtain different results by taking into account their demographic profiles and their dependency on apps usage. Finally, two sets of samples that consist of users who use paid apps and in-app purchase might determine how these samples are different in terms of apps usage, and it shall be explored further. 


\section{References}

Aulia, S. A., Sukati, I., \& Sulaiman, Z. (2016). A Review: Customer Perceived Value And Its Dimension. Asian Journal Of Social Sciences And Management Studies, 3(2), 150-162.

Baik, A., Venkatesan, R., \& Farris, P. (2014). Mobile Shopper Marketing: Assessing The Impact Of Mobile Technology On Consumer Path To Purchase. In Shopper Marketing And The Role Of In-Store Marketing (Pp. 1-25). Emerald Group Publishing Limited.

Baptista, G., \& Oliveira, T. (2015). Understanding Mobile Banking: The Unified Theory Of Acceptance And Use Of Technology Combined With Cultural Moderators. Computers In Human Behavior, 50, 418-430.

Have, K., Jain, V., \& Roy, S. (2013). Understanding The Orientation Of Gen Y Toward Mobile Applications And In-App Advertising In India. International Journal Of Mobile Marketing, 8(1), 62-74.

Biel, B., Grill, T., \& Gruhn, V. (2010). Exploring The Benefits Of The Combination Of A Software Architecture Analysis And A Usability Evaluation Of A Mobile Application. Journal Of Systems And Software, 83(11), 2031-2044.

Boyd, D. E., Kannan, P. K., \& Slotegraaf, R. J. (2019). Branded Apps And Their Impact On Firm Value: A Design Perspective. Journal Of Marketing Research, 56(1), 76-88

Candan, B., Ünal, S., \& Erciş, A. (2013). Analysing The Relationship Between Consumption Values And Brand Loyalty Of Young People: A Study On Personal Care Products. Management, 29-46.

Carter, S., \& Yeo, A. C. M. (2016). Mobile Apps Usage By Malaysian Business Undergraduates And Postgraduates: Implications For Consumer Behaviour Theory And Marketing Practice. Internet Research, 26(3), 733-757.

Castaldo, S., Premazzi, K., \& Zerbini, F. (2010). The Meaning (S) Of Trust. A Content Analysis On The Diverse Conceptualizations Of Trust In Scholarly Research On Business Relationships. Journal Of Business Ethics, 96(4), 657-668.

Cata, T., \& Martz, B. (2015). Comparing Mobile Apps Usability Characteristics For Designers And Users. Journal Of International Technology And Information Management, 24(4), 63-78. Chen, Q., Chen, Q., Zhang, M., Zhang, M., Zhao, X., \& Zhao, X. (2017). Analysing Customer Behaviour In Mobile App Usage. Industrial Management \& Data Systems, 117(2), 425-438. Chopdar, P.K., Korfiatis, N., Sivakumar, V.J. \& Lytras, M.D. (2018). Mobile Shopping Apps Adoption And Perceived Risks: A Cross-Country Perspective Utilizing The Unified Theory Of Acceptance And Use Of Technology, Computers In Human Behavior, 86, 109-128.

Cocosila, M., \& Igonor, A. (2015). How Important Is The "Social” In Social Networking? A Perceived Value Empirical Investigation. Information Technology \& People, 28(2), 366-382. Davis, F. (1989). Perceived Usefulness, Perceived Ease Of Use, And User Acceptance Of Information Technology. Mis Quarterly, 13(3), 319-340.

Deepak S. K, Purani, K. \& Viswanathan, S.A. (2018), Influences Of 'Appscape' On Mobile App Adoption And M-Loyalty, Journal Of Retailing And Consumer Services, 45, 132-141.

Deepak, S. K., Keyoor, P. \& Shyam, A. V. (2018). Influences Of 'Appscape' On Mobile App Adoption And M-Loyalty. Journal Of Retailing And Consumer Services, 45, 132-141.

Delone, W. H. (2003). The Delone And Mclean Model Of Information Systems Success: A Ten-Year Update. Journal Of Management Information Systems, 19(4), 9-30.

Delone, W. H. \& Mclean, E.R. (2003) The Delone And Mclean Model Of Information Systems Success: A Ten-Year Update, Journal Of Management Information Systems, 19:4, 9-30.

Ding, Y., \& Chai, K. H. (2015). Emotions And Continued Usage Of Mobile Applications. Industrial Management \& Data Systems, 115(5), 833-852. 
Dovaliene, A., Masiulyte, A., \& Piligrimiene, Z. (2015). The Relations Between Customer Engagement, Perceived Value And Satisfaction: The Case Of Mobile Applications. ProcediaSocial And Behavioral Sciences, 213, 659-664.

Finkelstein, A., Harman, M., Jia, Y., Martin, W., Sarro, F., \& Zhang, Y. (2017). Investigating The Relationship Between Price, Rating, And Popularity In The Blackberry World App Store. Information And Software Technology, 87, 119-139.

Gan, C., \& Wang, W. (2017). The Influence Of Perceived Value On Purchase Intention In Social Commerce Context. Internet Research, 27(4), 772-785.

Gao, L., Waechter, K.A. (2017). Examining The Role Of Initial Trust In User Adoption Of Mobile Payment Services: An Empirical Investigation. Information System Frontier, 19, 525548.

Groß, M. (2015). Exploring The Acceptance Of Technology For Mobile Shopping: An Empirical Investigation Among Smartphone Users. International Review Of Retail Distribution \& Consumer Research, 25(3), 215e235.

Hair, J. F., Hult, G. T. M., Ringle, C. M., \& Sarstedt, M. (2017). A Primer On Partial Least Squares Structural Equation Modelling (Pls-Sem). $2^{\text {nd }}$ Ed Thousand Oaks: Sage Publications. Hayes, A. F. (2009). Beyond Baron And Kenny: Statistical Mediation Analysis In The New Millennium. Communication Monographs, 76(4), 408-420.

Hew, J. J., Lee, V. H., Ooi, K. B., \& Wei, J. (2015). What Catalyses Mobile Apps Usage Intention: An Empirical Analysis. Industrial Management \& Data Systems, 115(7), 12691291.

Hirschman, E. C., \& Holbrook, M. B. (1982). Hedonic Consumption: Emerging Concepts, Methods And Propositions. The Journal Of Marketing, 92-101.

Holbrook, M.B. (1999) 'Introduction To Consumer Value', In M.B. Holbrook (Ed.) Consumer Value. A Framework For Analysis And Research, Pp. 1-28. London:Routledge.

Hsiao, C. H., Chang, J. J., \& Tang, K. Y. (2016). Exploring The Influential Factors In Continuance Usage Of Mobile Social Apps: Satisfaction, Habit, And Customer Value Perspectives. Telematics And Informatics, 33(2), 342-355.

Hsiao, K. L. (2017). Compulsive Mobile Application Usage And Technostress: The Role Of Personality Traits. Online Information Review, 41(2), 272-295.

Hsiao, K. L., \& Chen, C. C. (2016). What Drives In-App Purchase Intention For Mobile Games? An Examination Of Perceived Values And Loyalty. Electronic Commerce Research And Applications, 16, 18-29.

Hsiao, K. L., Shu, Y., \& Huang, T. C. (2017). Exploring The Effect Of Compulsive Social App Usage On Technostress And Academic Performance: Perspectives From Personality Traits. Telematics And Informatics, 34(2), 679-690.

Hsieh, H-Y. (2016). The Relationship Among Consumer Value, Brand Image, Perceived Value And Purchase Intention- A Case Of Tea Chain Store In Tainan City. Proceedings OfThe Eighth Asia-Pacific Conference On Global Business, Economics, Finance And Banking (Apl6singapore Conference), 1-10.

Hsu, C-L. \& Lin, J.C-C. (2016). Effect Of Perceived Value And Social Influences On Mobile App Stickiness And In-App Purchase Intention, Technological Forecasting And Social Change, 108, 42-53.

Hsu, C. L., \& Lin, J. C. C. (2015). What Drives Purchase Intention For Paid Mobile Apps?An Expectation-Confirmation Model With Perceived Value. Electronic Commerce Research And Applications, 14(1), 46-57.

Huang, G.H., \& Korfiatis, N. (2015). Trying Before Buying: The Moderating Role Of Online Reviews In Trial Attitude Formation Toward Mobile Applications. International Journal Of Electronic Commerce, 19(4), 77-111. 
Iqbal, M. (2019). App Download And Usage Statistics. Retrieved November 19 From Https://Www.Businessofapps.Com/Data/App-Statistics/

Jain, V., \& Viswanathan, V. (2015). Choosing And Using Mobile Apps: A Conceptual Framework For Generation Y. Journal Of Customer Behaviour, 14(4), 295-309.

Kim, M., Kim, J., Choi, J., \& Trivedi, M. (2017). Mobile Shopping Through Applications: Understanding Application Possession And Mobile Purchase. Journal Of Interactive Marketing, 39, 55-68.

Kim, S.C., Yoon, D. \& Han, E.K. (2016). Antecedents Of Mobile App Usage Among Smartphone Users, Journal Of Marketing Communications, 22 (6), 653-670.

Li, X. Su, X. Su, Hu, X. \& Yao, L. (2019). App Users' Emotional Reactions And Festival Satisfaction: The Mediating Role Of Situational Involvement, Journal Of Travel \& Tourism Marketing, 36:9, 980-997

Lin, Y. H., Guo, J. L., Hsu, H. P., Yang, L. S., Fu, Y. L., \& Huang, C. M. (2019). Does "Hospital Loyalty" Matter? Factors Related To The Intention Of Using A Mobile App. Patient Preference And Adherence, 13, 1283-1294.

Liu, C. Z., Au, Y. A., \& Choi, H. S. (2014). Effects Of Freemium Strategy In The Mobile App Market: An Empirical Study Of Google Play. Journal Of Management Information Systems, 31(3), 326-354.

Mackenzie, S. B., \& Podsakoff, P. M. (2012). Common Method Bias In Marketing: Causes, Mechanisms, And Procedural Remedies. Journal Of Retailing, 88(4), 542-555.

Maghnati, F., \& Ling, K. C. (2013). Exploring The Relationship Between Experiential Value And Usage Attitude Towards Mobile Apps Among The Smartphone Users. International Journal Of Business And Management, 8(4), 1-9.

Marakanon, L., \& Panjakajornsak, V. (2016). Developing And Examining A Model Of Perceived Quality, Perceived Value And Perceived Risk Affecting Customer Loyalty Of Environmentally-Friendly Electronic Products. Pertanika Journal Of Social Sciences \& Humanities, 24(4), 1481-1501.

Martin, S. (2019). Top Mobile App Development Trends Of The Year 2020 Retrieved On Https://Hackernoon.Com/Top-Mobile-Application-Development-Trends-In-2019-

5 bc 1 ba 19188

Mclean, G., Al-Nabhani, K. \& Wilson, A. (2018). Developing A Mobile Applications Customer Experience Model (Mace) - Implications For Retailers, Journal Of Business Research, 85, 325-336.

Milan, G. S., Zanchet De Lima, V., Eberle, L., De Toni, D. \& Bebber, S. (2019). Repurchase Intent Antecedents Of A Competitive Brand In The Smartphones Segment, Journal Of Marketing Communications, 25 (5), 457-476.

Nicholas, D. (2014). The Google Generation, The Mobile Phone And The'library'of The Future: Implications For Society, Governments And Libraries. Retrieved July 10, 2017 From Http://Ciber-Research.Eu/Download/20141105-Malaysia_Nicholas_Keynote.Pdf

Palomba, F., Linares-Vásquez, M., Bavota, G., Oliveto, R., Di Penta, M., Poshyvanyk, D., \& De Lucia, A. (2015, September). User Reviews Matter! Tracking Crowdsourced Reviews To Support Evolution Of Successful Apps. In Software Maintenance And Evolution (Icsme), 2015 Ieee International Conference On (Pp. 291-300).

Pentina, I., Bailey, A. A. \& Zhang, L. (2018). Exploring Effects Of Source Similarity, Message Valence, And Receiver Regulatory Focus On Yelp Review Persuasiveness And Purchase Intentions, Journal Of Marketing Communications, 24 (2), 125-145.

Podsakoff, P. M., Mackenzie, S. B., Lee, J. Y., \& Podsakoff, N. P. (2003). Common Method Biases In Behavioral Research: A Critical Review Of The Literature And Recommended Remedies. Journal Of Applied Psychology, 88(5), 879-903. 
Preacher, K.J. \& Hayes, A.F. (2004). Spss And Sas Procedures For Estimating Indirect Effects In Simple Mediation Models, Behaviour Research Methods, Instruments And Computers, 36, 717-731

Pura, M. (2005), "Linking Perceived Value And Loyalty In Location-Based Mobile Services", Managing Service Quality: An International Journal, Vol. 15 No. 6, Pp. 509-538.

Rauschnabel, P. A., Felix, R., \& Hinsch, C. (2019). Augmented Reality Marketing: How Mobile Ar-Apps Can Improve Brands Through Inspiration. Journal Of Retailing And Consumer Services, 49, 43-53.

Ringle, C. M., Wende, S., \& Becker, J. M. (2015). Smartpls 3. Boenningstedt: Smartpls Gmbh, Http://Www. Smartpls. Com.

Roma, P., Zambuto, F., \& Perrone, G. (2016). The Role Of The Distribution Platform In Price Formation Of Paid Apps. Decision Support Systems, 91, 13-24.

Roni, S. M. (2014). Introduction To Spss. Soar Centre Graduate Research School Edith Cowan University Joondalup, Australia.

Ruiz, I. M., Nagappan, M., Adams, B., Berger, T., Dienst, S., \& Hassan, A. (2017). An Examination Of The Current Rating System Used In Mobile App Stores. Ieee Software, 33(6), 86-92.

Sánchez-Fernández, R., \& Iniesta-Bonillo, M. Á. (2007). The Concept Of Perceived Value: A Systematic Review Of The Research. Marketing Theory, 7(4), 427-451.

Sheth, J. N., Newman, B. I., \& Gross, B. L. (1991). Why We Buy What We Buy: A Theory Of Consumption Values. Journal Of Business Research, 22(2), 159-170.

Singh, S. \& Zolkepli, I.A. (2018). New Wave In Mobile Commerce Adoption Via Mobile Applications In Malaysian Market: Investigating The Relationship Between Consumer Acceptance, Trust, And Self Efficacy, International Journal Of Interactive Mobile Technologies, Vol 12 (7), P112- 128

Suárez, A., Specht, M., Prinsen, F., Kalz, M. \& Ternier, S. (2018). A Review Of The Types Of Mobile Activities In Mobile Inquiry-Based Learning, Computers \& Education, 118, 38-55.

Summerfield, J. (2012). Which Is Best For Your Organization? Retrieved July 12, 2017 From Https://Qfuse.Com/Learning/Mobile-Websites-Vs-Mobile-Apps

Sweeney, J. C., \& Soutar, G. N. (2001). Consumer Perceived Value: The Development Of A Multiple Item Scale. Journal Of Retailing, 77(2), 203-220.

Tarute, A., Nikou, S., \& Gatautis, R. (2017). Mobile Application Driven Consumer Engagement. Telematics And Informatics, 34(4), 145-156.

Taylor, D., \& Levin, M. (2014). Predicting Mobile App Usage For Purchasing And Information-Sharing. International Journal Of Retail \& Distribution Management, 42(8), 759774.

Van Noort, G., \& Van Reijmersdal, E. A. (2019). Branded Apps: Explaining Effects Of Brands' Mobile Phone Applications On Brand Responses. Journal Of Interactive Marketing, 45, 1626.

Verkasalo, H., Lopez-Nicol, C., Molina-Castillo, F. J., \& Bouwman, H. (2010). Analysis Of Users And Non-Users Of Smartphone Applications. Telematics And Informatics, 27(3), 242255.

Wang, C. (2014). Antecedents And Consequences Of Perceived Value In Mobile Government Continuance Use: An Empirical Research In China. Computers In Human Behavior, 34, 140147.

Wang, H. Y., Liao, C., \& Yang, L. H. (2013). What Affects Mobile Application Use? The Roles Of Consumption Values. International Journal Of Marketing Studies, 5(2), 11-22.

Williams, P. And Soutar, G.N. (2000) 'Dimensions Of Customer Value And The Tourismexperience: An Exploratory Study', Paper Presented At Australian And New 
Zealandmarketing Academy Conference, 28 November-1 December.

Woodruff, R. B. (1997). Customer Value: The Next Source For Competitive Advantage. Journal Of The Academy Of Marketing Science, 25(2), 139-153.

Wu, J. J., Shu-Hua, C., \& Kang-Ping, L. (2017). Why Should I Pay? Exploring The Determinants Influencing Smartphone Users' Intentions To Download Paid App. Telematics And Informatics, 34(5), 645-654.

Xiao, G., \& Kim, J. O. (2009). The Investigation Of Chinese Consumer Values, Consumption Values, Life Satisfaction, And Consumption Behaviors. Psychology \& Marketing, 26(7), 610624.

Xinwei Su, X.L., Hu, X. \& Yao, L. (2019). App Users' Emotional Reactions And Festival Satisfaction: The Mediating Role Of Situational Involvement, Journal Of Travel \& Tourism Marketing, 36(9), 980-997

Zeithaml, V. A. (1988). Consumer Perceptions Of Price, Quality, And Value: A Means-End Model And Synthesis Of Evidence. Journal Of Marketing, 52(3), 2-22.

Zhang, C. B., Li, Y. N., Wu, B., \& Li, D. J. (2017). How Wechat Can Retain Users: Roles Of Network Externalities, Social Interaction Ties, And Perceived Values In Building Continuance Intention. Computers In Human Behavior, 69, 284-293.

Zhang, T., Lu, C. And Kizildag, M. (2018), "Banking "On-The-Go": Examining Consumers' Adoption Of Mobile Banking Services", International Journal Of Quality And Service Sciences, Vol. 10 No. 3, Pp. 279-295.

Zhao, Z., \& Balague, C. (2015). Designing Branded Mobile Apps: Fundamentals And Recommendations. Business Horizons, 58(3), 305-315.

Zolkepli, I. A., \& Kamarulzaman, Y. (2015). Social Media Adoption: The Role Of Media Needs And Innovation Characteristics. Computers In Human Behavior, 43, 189-209.

Zolkepli, I.A., Kamarulzaman, Y. \& Kitchen, P. (2018). Uncovering Psychological Gratifications Affecting Social Media Utilization: A Multiblock Hierarchical Analysis, Journal Of Marketing Theory And Practice, Vol 26 (4), 412-430

Zolkepli, Izzal Asnira (2016). Domination Of Mobile Apps Market: The Effect Of Apps Value On Apps Rating And Apps Cost In Determining Adoption, Proceedings Of Penang International Symposium On Advances In Social Sciences And Humanities (Pisassh), 30-31 ${ }^{\text {st }}$ January, Penang, Malaysia 